\title{
"The debates on the representative firm and increasing returns: Then and
}

\author{
now"
}

\section{by G.C. Harcourt and S. Blankenburg *}

\begin{abstract}
I
There is something completely archaic yet very modern about the tone and issues of the 1920s debates in the Economic Journal on the representative firm and increasing returns, also often referred to as 'the cost controversy'. Then, as now, applied economists, "realitics", as Sir John Clapham called them, and theoretical economists ('analytics') were often a race apart who neither properly understood nor appreciated each other's roles and approaches. Then, as now, views differed on whether or not theory had to be directly applicable in explanations of 'real world' observations and much misunderstanding occurred because the separation between logically coherent 'high theory' in its own domain and, a separate issue, its direct applicability, was not made by protagonists in an argument. Or, if it were, one side would be concerned with the former, the other with the latter, without either making this understanding explicit.
\end{abstract}

For these confusions and misunderstandings, Marshall must take his full share of the blame. Though this distinction was clear in his own mind, in the presentation of arguments in his Principles it is purposefully blurred because of his desire to be read by businessmen (sic) as well as by his pupils and the profession generally. Thus the text especially of the Principles often reads as though it were a narrative about real-life happenings, admittedly explicitly confined in the main to normal periods but meant to call up in the readers' minds their own observations and experiences. Yet Marshall's powerful theoretical mind provided an underlying but often hidden structure (or one confined to footnotes and appendices) of explicitly set out theoretical pre-suppositions and arguments. This took the same subtlety of mind (and foxiness of character) as Marshall's to be clearly discerned and attended to in the interpretation of the text.

It must also be remembered that at this time, not only was the distinction between the domains of theory and practice in the discipline being worked out, not least by Frank

\footnotetext{
* While this paper is a joint production, G C H is primarily responsible for the first draft of sections I to VI and S. B. for the first draft of sections VII to IX. S. B. would like to thank Richard Arena for very fruitful discussions that helped to clarify some of the arguments advanced. The usual disclaimer applies.
} 
Knight in what was to become Risk, Uncertainty and Profit (1921) ${ }^{1}$, but also the classical notion of a freely competitive environment which in the writings of Adam Smith and Karl Marx, for example, was the dynamic setting for distribution, accumulation and growth as well as a theory of price formation, was being refined into the rigorous but static characteristics of the price-taking model on which students are brought up today in courses on microeconomics. This was to become a coherent, rigorous, logically watertight but basically an un-illuminating and ineffectual explanation of the behaviour of actual firms, industries and, ultimately, economies. For though it was possible to find price-taking behaviour hinted at in the Principles, its twin assumption of perfect foresight which together defined perfect as opposed to pure competition was conspicuous by its absence in the text of the Principles (but perhaps not necessarily so in its underlying structure of a long-period stationary state).

Because also in much of the discussion it is not always clear whether it is the long period or the short period or both that are being analysed, there is not always a clear distinction made between analysis of production and price-setting as such, on the one hand, and accumulation and investment, including the choice of technique of production within the investment decision, on the other. This meant that when the shapes of cost curves were examined, it was not always clear whether it was a production decision or an investment decision that was being analysed. That is to say, whether when an increase or decrease in production is considered, the analyst was asking what may reasonably be expected of changes in costs, if any, in a given situation of the here and now; or, what happens to the level of long-period costs at different potential levels of production of the plants chosen to be invested in, is the subject of analysis. These points were to become clear in Edward Chamberlin's discussion in an appendix to his Theory of Monopolistic Competition (1933) of the long-period envelope cost curve. There, he overcomes the misconceptions in Jacob Viner's classic statement (Viner 1932) of the issues, misconceptions associated with the contribution of his obstinate Chinese draftsman, to show that to call the long-period curve an envelope was to use a serious misnomer, because the curve did not have a separate existence from the possible short-period plant curves in a given situation, the relevant parts of which it is made up.

II

There was always a potential contradiction in Marshall's 'vision'. He had 'invented' supply and demand analysis in a way which allowed him to handle that elusive

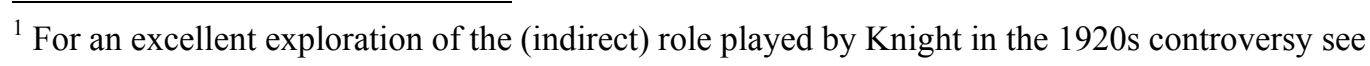


but vital variable time, by distinguishing between the market, short and long period where what was and was not locked up in the cet. par. pound was decided by the economist/analyst. He also saw societies as evolving interrelated organic entities; and he knew but tried not to let on in too damaging a manner that the basically static analysis of his supply and demand functions and periods could not handle in a fundamental way the other aspect of his understanding. Though he wanted 'economic science' to be fruit- as well as light-bearing, he was also committed to a defence of a competitive environment which was sustainable, despite substantial changes over time in institutions. In particular, he wanted his 'trees in the forest' analogy of competitive conditions to survive the emergence of monopolies and oligopolies accompanied by the emergence and then dominance of joint stock companies as the main form of industrial organisation. He knew of what he considered to be Cournot's error (as a description of the real world as opposed to being a logical argument in its own domain), that increasing returns in firms and competition could not be enduring bedfellows. Once one firm got ahead of its rivals it could undersell them and take over the industry, i.e., become a monopoly.

Marshall's answer to this was not couched in terms of Schumpeter's creative destruction - a temporary monopoly firm exploiting an innovation made monopoly profits which attracted imitators in to compete them away - nor Joan Robinson's fish in a pond whereby the bigger fish came to dominate - eat up - the smaller ones. Rather he introduced the device of the representative firm which allowed the real world facts of increasing returns, internal and external economies, to be accommodated without destroying the viability of competitive environments in the long run. The representative firm was a forerunner of the modern representative agent, the purpose of which is to stand in for the behaviour of the group (for Marshall, the industry, for the moderns, the whole economy) while having in fact no actual existence in reality.

There were minor policy recommendations allowed; they were spelt out in more precise analytical detail than Marshall would have permitted himself to do by his in effect chosen successor, Pigou. ${ }^{2}$ By distinguishing between private and social costs and recognising the existence of decreasing and increasing returns, Pigou built on Marshallian foundations to establish carrot and stick measures (subsidies and taxes) to induce social optima of a limited and commonsense variety. All this was the fare of the various editions of The Economics of Welfare.

\footnotetext{
Marchionatti (1999 and 2000, pp. 53-55).

${ }^{2}$ For a detailed analysis of developments regarding increasing returns and external economies up to 1914 see Whitaker (1982).
} 
It was here that Clapham entered the fray with his teasing, emperor has no clothes on, article, "On empty economic boxes" (1922). Clapham was a no-nonsense economic historian who had a detailed knowledge of agricultural, industrial and financial firms and industries, and of the interrelated systems to which they belonged. He had read his Marshall and Pigou but felt that the gap between the carefully and precisely stated propositions by the former two economists (especially in Pigou) and the complexity arising from his own observations was virtually unbridgeable. Especially was this so when the preliminary step to the policy of suggesting a subsidy or a tax was the need to classify specific industries as subject to either decreasing or increasing returns. He took as his illustration a visit to a hat factory; he asked in which of the boxes marked on the outside as increasing or decreasing returns industries would the specific industry to which the hat factory 'belonged' be found. Indeed he wondered whether the neat products of the theory homogeneous, competitively sold - could ever be matched to the great variety of actual products which came under the general heading of hats. From this he next wondered aloud whether the definition of an industry could ever be pinned down in practice; and so on. In doing so he was contributing to the general debate, on both sides of the Atlantic, concerning the natures of applied and theoretical work. As we have mentioned above, this involved a tightening up of the definition of perfect competition, taking it away from the looser but more dynamic concept it had in the guise of the free competition of the Classicals, Marx and Marshall to the price-taking, perfect foresight model. The latter was also distinguished from pure competition which only assumed price-taking. (Smith, Marx and Marshall would never have thought of trying to analyse a world in which the future was known with certainty.) In the December 1922 Economic Journal (Clapham's article had appeared in the September issue, my, things were published quickly in those days), Pigou replied to the critique by his fellow King's man. He thought that the categories analytic and realitic were themselves empty - no actual person really fell into either category. Pigou distinguished between two sorts of knowledge. The first is 'pure' knowledge about implications such as we find in logic and mathematics (Ken Rivett, GCH's methodology teacher at Melbourne university, called these necessary propositions, true by definition). The second is realistic knowledge, knowledge of subject matter presumed to be actual, the characteristics of the data studied and taught by physicists. He also classified knowledge into that which can or cannot give direct help in the practical conduct of affairs (always a Pigovian emphasis).

If Clapham were to be taken literally, there was no point in trying to analyse returns, whether increasing or decreasing, because even if we filled the empty boxes, we 
would still receive no help in practice: A non sequitur, says Pigou, adding that by far the greater part of knowledge which history aims at is totally irrelevant in practice. Nevertheless, because knowledge by itself is of little value we must try to make more Jevons's, people equally at home in both fields. In the meantime, we should substitute cooperation between the two types for quarrels on the basis of imperfect understanding of the deficiencies of one another's method. So, Professor Clapham, would you please pass the salt!

\section{III}

Throughout the debates, explicit mention is made by the protagonists about whether the short period or the long period or both is the appropriate context. Similarly, an explicit distinction is made between the processes of production, on the one hand, and accumulation or investment which allows new methods to be put in place in firms and industries, on the other. But, having said this, it must also be said that these various aspects were also a source of a great deal of confusion and muddle which were not really cleared up until after the 1930 Economic Journal symposium which closes our period of examination.

In our view, the watershed which allows these issues to be settled is Chamberlin's Appendix B in the 1950 sixth edition of his classic on the relationship between the short-period average cost plant curves and the long-period misnamed envelope average cost curve - misnamed, because as Chamberlin makes clear, the envelope curve is not an envelope, something placed around something else, but is in fact segments of (with continuity, points on) succeeding plants curves showing the least-cost method of producing each level of output in the given situation. As we know, Chamberlin argued that the reasons for the $\mathrm{U}$ shape of the plant curves are completely different from those responsible for the $U$ shape of the long-period curve. The former is due to the application of the law of variable proportions to production with each possible plant; the latter is due to economies of scale outweighing diseconomies as we pass from one plant to another, and then to a reversal of the dominance between the contending factors.

For our purposes, the important point to note is that the construction of the long-period curve from its constituent plants is telling us as observing economists (and businesspeople and profit-seeking accumulators) what is the appropriate choice of technique for anticipated future levels of output, i.e., it is relevant for the investment decision now and, once embodied, for production decisions later on. In a full analysis, such as we were to get in Wilfred Salter's 1960 classic, the amount of investment and the change 
in capacity in individual firms would depend on how many existing plants remain profitable in the sense of positive expected quasi-rents in any given situation and how much of production levels deemed to be profitable would need to come from the new plant and methods introduced in the current investment expenditure associated with the optimum points on the long-period curve. Seen like this, much of the cross purpose and non-meeting of minds in the debates of the 1920s disappear.

\section{IV}

At the end of Piero Sraffa's contribution to the 1930 symposium (Keynes 1930), he makes absolutely clear where he stands on Marshall's theory:

"We seem to be agreed that [Marshall's] theory cannot be interpreted in a way which makes it logically consistent, and at the same time, reconciles it with the facts it sets out to explain. Mr. Robertson's remedy is to discard mathematics, and to suggest that [Sraffa's] remedy is to discard the facts; perhaps I ought to have explained that ... I think it is Marshall's theory that should be discarded." (Sraffa 1930, 93).

At the Corfu Conference on capital theory in the late 1950s, Sraffa (1961) set out the standards he set himself (and the subject) concerning measurement, theory and the criteria they should meet within the context of capital theory. He first distinguished between measurement by statisticians “... only approximate ... provided a suitable field for work in solving index number problems"; the second concerned theoretical measures which "required absolute precision. Any imperfections ... knocked down the whole theoretical basis". The definition of capital in theory must therefore be kept "separate from the needs of statistical measurement ... J.B. Clark, Böhm-Bawerk and others intended to produce pure definitions of capital, as required by their theories ... contradictions ... pointed to defects in the theory". (Sraffa 1961, 305-6).

Sraffa's 1925 and 1926 articles (the first few pages of Sraffa 1926 constitute a summary of the complex and detailed arguments of the much longer 1925 article) are principally attacks on the logical foundations of Marshall's theory of competitive value. (Often, though, it is Pigou's version of it that Sraffa has within his sights.) The theory itself depends on "the fundamental symmetry existing between the forces of supply and demand", using the method of partial equilibrium ("particular equilibrium" in Sraffa's terms, Sraffa 1926, 539), so that "the essential causes determining the price of particular commodities may be [...] grouped together so as to be represented by a pair of intersecting 
curves of collective demand and supply" (Sraffa 1926, 535). Sraffa's conclusion is that the only case which is logically consistent with the approach is one of constant costs "in respect of small variations in the quantity produced". (Sraffa 1926, 541). In a footnote on p. 541 he stresses that constancy comes from an "absence of causes which tend to cause the cost either to increase or diminish", not from an improbable "accidental balancing of two opposite tendencies", as Sidgwick and Marshall would have it.

The criticism is a logical and methodological one, a search for a set of conditions which allows the method logically to be applied. Sraffa starts by reminding us that the 'laws' of returns historically belonged in different parts of the discipline, diminishing returns in the theory of distribution (rent) rather than in a discussion of relative values and prices, increasing returns in discussions of 'general economic progress' rather than in a discussion of "increase[s] in the scale of production" (Sraffa, 1926, 557). Combining them together, as modern theory now did (and does) in a theoretical whole, was restrictive and contradictory. Especially was this true of increasing returns, for to be consistent with competitive theory (they could of course be a fact of life) the division of labour had to be "limited to the case of independent subsidiary factories coming into existence as the production of an industry [increased]" (Sraffa 1926, 537). Internal economies associated with the growth of individual firms had to be "entirely abandoned $[. .$.$] incompatible with$ competitive conditions" (Sraffa 1926, 537-8), so that "external economies" were more and more emphasised.

Diminishing returns were traditionally associated with the existence of a fixed factor and in the (then) modern theory (but not in Classical Political Economy) with the short period. But this implied to Sraffa that the more broadly an industry was defined the more likely it was that diminishing returns would arise from the use of the one factor. Whereas the more homogeneous we made the commodity within an industry (suppose we move from agriculture to fruit) "the greater will be the possibility that the forces which make for increasing returns will predominate" (Sraffa 1926, 538). The effects are similar to those of time, especially the time allowed for adjustments to occur and have an impact on returns.

Most importantly, the independence assumption relating to demand and supply schedules is now at risk. For, as Sraffa says, "it is precisely in [the] category that ... when a variation in the quantity produced by [an] industry ... sets up a force which acts directly ... upon its own costs [and] the costs of other industries [so that] the conditions of the 'particular equilibrium' which it was intended to isolate are upset ... that the applications 
of the laws of returns fall, in the great majority of cases" (Sraffa 1926, 539). For diminishing returns, we are left with "that minute class of commodities in the production of which the whole of a factor is employed" (Sraffa 1926, 539). For increasing returns, we only have those economies ("most seldom to be met with [in practice]") which are external to the firm but internal to the industry (Sraffa 1926, 540). So, if we are to use partial equilibrium analysis, "in normal cases the cost of production of commodities produced competitively ... must be regarded as constant in respect of small variations in the quantities produced." (Sraffa 1926, 540-41).

In the 1926 article, Sraffa turned his back on general equilibrium as a way out and spawned instead what became the imperfect/monopolistic competition revolutions which allowed the existence of lower costs at higher rates of output because of demand constraints in imperfectly competitive markets (but see footnote 7 below).

\section{V}

In 1928 Joseph Schumpeter published in the Economic Journal, a profoundly cerebral article on the instability of capitalism. He asked: if we abstract from political and other shocks to the system, including certain classes of technical advances, is a competitive economy a stable system in the sense that it tends to a level of operation which is repeatable? (It was Walras's principal ambition to show that indeed it was.) In the article Schumpeter reveals his views on the nature of economic theorising and on what he means by stability. Thus in the 'real world' a system could behave in a most unstable way because of political shocks, e.g. a war or a natural calamity such as flood or fire (or even foot and mouth) and yet be internally stable in its cet. par. operation. In making this distinction he was justifying his view that Walras was the role model for theorists, yet his own vision of the impact of innovations in the accumulation carried out by his entrepreneur heroes and continuous technical change could be logically fitted into a theoretical analysis which started from a Walrasian general equilibrium system in equilibrium. In this manner Schumpeter hoped to deal with the issues that the other contributors in the representative firm and increasing returns debates were grappling with.

His article appeared in the same issue of the Economic Journal as the article by Lionel Robbins on the representative firm (which Whitaker (1989) judged not to have been of lasting value or importance but which had much notice taken of it when it was first 
published. ${ }^{3}$ ). He argues that Marshall put in the representative firm as an after thought and that he never made the section of the Principles which contains it correct, quoting Keynes on Marshall in support.

His criticism turns on the meaning of average implied by representative and whether in equilibrium a representative or average entrepreneur (or manager) is a viable or necessary concept. In doing this he has more Hubert Henderson's entrepreneur or manager than Marshall's own practice in mind. Robbins was to follow up this discussion with his more lasting contribution on the ambiguity of the notion of stationariness in economic analysis, a discussion which has particular relevance for misunderstandings in capital theory, even today. ${ }^{4}$

\section{VI}

Now we come to the climax of the debates, the symposium organised by Keynes in the March 1930 Economic Journal. There were three contributors - Dennis Robertson, Piero Sraffa and Gerald Shove. Keynes saw Robertson as a stout defender of old Marshall, representative firm in hand, Sraffa as extremely negative (so what is new?) and Shove as original and constructive, working within the Marshallian tradition but refusing to accept the representative firm as the only way of tackling the issues involved.

Robertson responded to Robbins's view that normal profit is what is needed to keep particular individuals in an industry so that it is determined by what they could get elsewhere and is therefore not a unique figure for the industry (or the economy as a whole). ${ }^{5}$ Robbins had criticised Henderson on these points and Robertson now defended him. According to Robertson, Henderson was describing those on the road to elimination from the industry because of their inadequacies. At any moment of time, however, similar types enter the industry so leaving the industry in equilibrium. Robertson reiterates the proposition that the concept of the representative firm is essential to our understanding of the theory of increasing returns because it helps us to tackle Cournot's difficulty associated with increasing returns: how equilibrium can exist without the whole supply being concentrated in the hands of one producer. He lists recent answers. First, Schumpeter (and

\footnotetext{
${ }^{3}$ Robbins is listed as being at New College, Oxford, but he writes as though he had already begun his long reign at the LSE.

${ }^{4}$ See Kurz (2000) for a discussion of this in the context of Wicksell's approach to capital theory over his life time.

${ }^{5}$ This incidentally indicates how concentrating on partial equilibrium analysis takes attention away from the Classical and Marxian emphasis on the need to explain what determines the rate of profits of the economy as a whole in a competitive setting, a concept Sraffa was to return to in Production of Commodities by Means of Commodities (1960).
} 
others) deny the validity of a long-period falling supply curve (except as a record of historical events); it cannot be the series of conditional statements which it is required to be. To Robertson this is a counsel of despair which was considered and rejected by Marshall (so that's alright then). Marshall stressed that the firm's experience is not to be considered the equivalent of the industry's experience, especially in the long period.

Then there is Sraffa who resorts to a theory of monopoly which will yield a determinate result (always one of Sraffa's aims for theory). Robertson reminds us that as always it is all in Marshall, this time in footnote. 1 on p.458 as Marshall's auxiliary argument, the central point of the economics of imperfect competition in a footnote. Pigou's answer depends upon there being external economies of large-scale production at the level of the industry even though individual firms work under conditions of decreasing returns. Pigou accepts internal economies of large-scale production but these have been ruled out by Sraffa, not because they do not exist but because Marshall's partial equilibrium method could not be used in their presence. For Pigou the representative firm is one for which there is an optimum size for each scale of aggregate output beyond which there are no further internal economies. (He has also transformed the representative firm into the equilibrium firm.) For Pigou but not for Sraffa, external economies are sufficient to ensure this.

Allyn Young (1928) extended the concept of external economies to include lower costs resulting from progressive division and specialisation of industries, the essential part of the process by which increasing returns are realised. (This insight was to guide Kaldor's writings for all of his working life.) Pigou built on the insight to suggest that these external economies allow increasing internal economies to an increase in the size of individual firms as industries expand, due to growing specialisation. This is both possible and plausible, but it is not the line that comes from either Marshall or observed fact. Robertson thinks it is the response to increasing demand for the industry's products by individual firms wanting to get the benefits of large-scale organisation and plant which are known but not yet brought into existence by specialisation or by other ways. Marshall's trees of the forest were meant to explain this idea and allow increasing returns to exist in the industry yet competition between firms also to prevail. Individual firms are not representative firms and they must expand as the representative firm does when overall demand increases. Hence no one individual firm will ever have a monopoly of the whole trade. How, asks Robertson, would Robbins make this point once he has scrapped the representative firm? 
Enter now Piero Sraffa. Why, he asks, if internal economies were available were they not taken advantage of? And if they are, why do they cease at (long-period) equilibrium - a point of constant returns! Sraffa's answer was to find out what assumptions were implicit in Marshall's theory and, in the event, he thought Marshall's theory should be discarded.

The stage is now set for Shove. He accepts that Robertson's piety as one way out, that his account of the role of the representative firm in Marshall's theory of competitive equilibrium is correct. But Shove also sides with Robbins, arguing that the problem can be solved without introducing the representative firm at all. In showing why he would draw on an "unpublished study of the relations between cost and output on which [he had] been engaged for some years" (Shove, 1930, 94).

To start with we must allow for those characteristics of long-period equilibrium which its inventor Marshall intended the representative firm to display. First, if an entrepreneur has a special aptitude for the work he/she is engaged in, his/her earnings will be much greater than the return he/she would get elsewhere and that which others in the industry with the same general capacity but not special advantages would receive. So the rent to the former is compatible with equilibrium and admits of wide variations in the rate of profit received by individual entrepreneurs.

Secondly, luck plays an important part in determining the actual earnings of individual entrepreneurs; so equilibrium requires not the equality of actual earnings, but of the mathematical expectation of earnings for similar units in different uses. Thirdly, the profits of the firm (apart from luck) differ at different stages of its career so there is no tendency for firms to show the same rate of profit unless they are at the same stage of development. (The same is true for skilled employees whose earnings are low when learning, rise to a maximum when fully equipped and decline when old age comes.)

Fourthly, the equilibrium of the industry as a whole does not imply that all (indeed any) of its individual firms are in equilibrium. The requirement is that aggregate output is unchanged; but some firms may be expanding, others declining, such as to offset each other overall. For equilibrium it follows that a general expansion or contraction should not be profitable.

The representative firm is an appropriate indeed brilliant device for displaying facts when we want to depict equilibrium as resulting from the rise and fall of individual 
houses of business. But when we look at the ebb and flow of resources of all kinds from one use to another, a different method is needed.

"We must then say that the attraction exerted by a particular occupation on a particular unit is the mathematical expectation of earnings in that occupation for a unit of resources with the character and aptitudes of this one (thus allowing for (1) and (2) [above]); that this expectation is to be reckoned by summing the series of its probable earnings at each stage of its career (thus allowing for (3)); and that it must be calculated on the assumption that resources within the industry ... are distributed between the firms in the most profitable way (thus allowing for (4)).” (Shove, 1930, 96, emphasis in original).

Moreover, Shove argues convincingly that there are numerous equilibrium points, each one of which corresponds to a specified starting point. (So path-dependence is not that new.) To Shove the economic problem represented by the real world is more a question of sorting out and fitting each into its appropriate niche, a vast number of heterogeneous individuals and activities than of regulating and directing into proper channels large homogeneous streams of standardised productive agents. Robertson does not agree because he wants to build up supply schedules by aggregating the supply schedules of various factors of production. But this can only be done if factors of production can be expressed in quantities alone and in a measure which is independent of value!

For Shove, when we try to unravel the relations between industry size and the efficiency of the businesses which make it up, we must distinguish between, first, improvements in organisation due to an increase in the output of the industry as a whole; and secondly, improvements which are due to increases in the output of individual firms, with industrial output remaining unchanged. According to Shove, Marshall had rolled the two together. Expansion under the second head causes both increases and decreases in efficiency so that the most efficient size is where they just offset each other. Under the first head, all changes which increase efficiency must be related to increases in industry size alone. This means that increases in the size of firms are governed by increases in the size of the industry. (Shove refers us to Marshall, pp. 459-60 for confirmation.)

Shove's most telling point is that time is missing from Pigou's and Robertson's diagrams. They have overlooked the crucial point that the enlargement of the total volume of trade may increase the speed at which individual businesses can grow. His final coup de grace is that Marshall's original trees of the forest analogy is no longer typical. Rather, most firms survive indefinitely, rising and falling with changes in the conditions of trade 
(i.e., over the cycle). Marshall had recognised this by changing 'is' to 'was' in later editions of the Principles as he could no longer ignore the implications of the rise of joint stock companies.

\section{VII}

20 years after its publication, Schumpeter credited Keynes with "a stroke of editorial genius" for having organised and published "a symposium (D.H. Robertson, G.F. Shove, and P. Sraffa) on the matter ('Increasing Returns and the Representative Firm [...]) that is still eminently worth reading." (Schumpeter 1994 [1954], fn 53, 1046). 50 years on, there are at least two reasons why not only the symposium, but also many of the original contributions to the controversy, are still - or perhaps once again - 'eminently worth reading'. First, it is important not to consider the controversy exclusively from the perspective of the formal solutions and models that now form part and parcel of textbook chapters on imperfect competition and industrial organisation. From this technical point of view, the debate is archaic. However, these models reflect only some of the ideas raised in the debates. In particular, they ignore the questions raised by Sraffa and Young (and to a lesser extent also by Schumpeter) about the fundamental inability of marginalism to accomodate the analysis of dynamics and economic progress. The relationship between statics and dynamics, as well as methodological questions about the 'realism' of economic analysis, are as much at the heart of the controversy as the nitty-gritty detail and technicalities of the collective attempt to come to grips with the microeconomics of Marshallian price theory. Yet they received much less attention.

Secondly, a fresh look at the less formal aspects of the controversy seems particularly pertinent in the light of the recent renewed interest of neoclassical macroeconomists in dynamic analysis and in the explanation of technical change and economic growth. Put briefly, the 1920s controversy effectively ended the reign of Marshallian economics as the dominant paradigm of economic thought. From this critical point of departure, the discussion moved in three main directions: the exploration of the potential of Walrasian (and Paretian) general equilibrium theory (Arrow-Debreu, Hahn), Sraffa's alternative asymmetric theory of prices, distribution and reproduction, and endogenous theories of innovation, growth and development based on the principle of cumulative causation (Kaldor, Myrdal, Schumpeter). While Sraffa's 1960 contribution was largely ignored by the mainstream, the scope and usefulness of neoclassical general equilibrium theory was undermined by a number of developments. These include the results of the capital theory controversies of the 1950s and 1970s, the defeat of the microfoundations project based on aggregative econometrics exemplified in the impossibility to remove the arbitrariness of 
aggregate excess demands and the failure to provide a proof of the existence of a general equilibrium position for the case of imperfectly competitive economies (Rizvi 1994a, 1994b). More recently - and arguably at least partly in response to these developments- the 'new classical' macroeconomics and the new endogenous growth theory (EGT) emerged within the neoclassical general equilibrium paradigm. What both have in common, is serious amnesia as far as the impasse reached by general equilibrium theory in the 1970 s is concerned. Pasinetti 's assessment of the fate of the 1950s and 1970s capital theory controversies equally applies to the other developments mentioned above: "Amnesia on such a vast scale can only be explained by more appropriate terms, such as 'suppression' or 'repression' or 'removal'. This is, perhaps, one of the most intriguing examples of that process described by Kuhn [...], through which dominant 'normal' science suppresses, and thus ignores, the cases of contradiction and anomaly it bears within." (Pasinetti 2000a, 412). The result is economic theorising that applies assumptions, such as the equality of demand and supply, and concepts, such as aggregate production functions, which in the past have been found to be either based on ad hoc reasoning or logically inconsistent 'as if they were part and parcel of everyday economic reality, not the slightest doubt being shown about them' (Pasinetti 2000a, 416).

It is against this background that the less formal insights contained in the 1920s debates regarding the relationship between static and dynamic analysis and the (methodological) question of realism seem to us to be of renewed relevance for a critical assessment, in particular, of the latest foray of neoclassical general equilibrium theory into dynamic analysis, i.e. EGT. Before having a closer look at EGT, we briefly summarise the relevant issues raised in the controversy, mainly by Sraffa and Young.

Sraffa's critique of Marshall extends beyond his careful analysis of the limiting cases in which partial equilibrium analysis can accommodate an industry supply curve with variable costs to a fully-fledged criticism of marginalism. In his 1925 paper, Sraffa's central concern is with the restrictions a theory of prices based on marginalist reasoning imposes on the analysis of production and accumulation in that it generates an artificial requirement of a functional relationship between costs and output. There is a specifically methodological dimension to Sraffa's critique of (Marshallian) marginalism. While this follows directly from his substantial objections to the symmetrical treatment of production and consumption it deserves separate attention. What Sraffa objects to repeatedly is the lack of realism and practical relevance of the marginalist "theory of competitive value" (e.g.1926, 535). The initial criterion by which to judge the validity of any theory is, of course, its logical consistency. If, however, the theory can be made logically consistent 
only for very exceptional cases, its practical relevance is questionable. This sums up Sraffa's approach to Marshall's ceteris paribus construction. His discussion of possible remedies or solutions as well as his (occasional) remarks on the way in which the particular constructions and premises underlying this approach have been arrived at $\mathrm{do}^{6}$, however, suggest that there are two different meanings to this general charge of practical irrelevance. As Sraffa explicitly recognises, the fact that, for any practical purposes, partial equilibrium analysis is useless does not exclude the possibility that this deficiency is purely due to given scientific limitations in handling complexity. It follows that the realism of the approach might increase, without the need to fundamentally question or abandon essential premises such as the symmetry assumption, once the subject has advanced sufficiently "to extend the field of investigation so as to examine the conditions of simultaneous equilibrium in numerous industries" $(1926,541)$. In this sense, Sraffa's critique of partial analysis is an internal one. In another sense, however, the charge of a lack of realism goes much further. In the same passage in which he discusses the hypothetical possibility of general equilibrium analysis to resolve the problem of cost-output interdependencies, he adds that, in the case of increasing returns, this still leaves us with "the impossibility of confining within statical conditions the circumstances from which they originate" (1926, 541). Sraffa then goes on to explore the possibilities of a theory of imperfect competition as a way out of the conundrum, but he abandoned this route shortly afterward and ultimately chose to develop an asymmetric theory of prices, distribution and reproduction. While there is much debate as to how and when exactly his (largely undocumented) change of mind came about ${ }^{7}$, it is worthwhile pointing out that this later development is consistent

\footnotetext{
${ }^{6}$ See Sraffa (1926, fn 1 541). In the 1925 article he makes the following remark on Marshall's role in popularising the 'fundamental symmetry' of demand and supply forces: "It is only in the Principles of Economics that the theory appeared in its definitive form. The radical change that this work precipitated in the substance of the laws of variation of costs were largely unnoticed, while the theory of value based on the 'fundamental symmetry' of the forces of demand and supply, of which those laws are necessary premises, remained unchanged. In essence, the foundations were replaced without the building standing above receiving a single jolt from it all, and it was the great ability of Marshall which allowed the transformation to pass unnoticed. If he had given the originality of the new conception the prominence it deserved, perhaps it would not have been received without opposition. By presenting it as something well-known and lacking novelty, almost as a commonplace, he was able to have it accepted as a tacit compromise between the necessities of the theory of competition, which are incompatible with the decrease of individual cost, and the necessity not to stray too far from reality that (being far from perfect competition) presents numerous cases of individual decreasing costs of this kind." $(1925,347)$. ${ }^{7}$ Dardi (2000), based on recent studies of Sraffa's archive papers, offers a comprehensive and convincing account. His essential point is that Sraffa turned his back on imperfect competition once he realised (shortly after his 1926 contribution) that this attempt to reconcile the theory of value with increasing returns meant that subjective and strategic considerations impervious to rigorous analysis would have to be given pride of place. This is not to say that Sraffa already had some form of alternative inter-sectoral simultaneous equilibrium analysis in mind when formulating his critique of Marshall (i.e., we agree with Mongiovi 1996 on this point), only that neither is there a reason to assume that there is no continuity at all between the Sraffa 1926 and Sraffa 1960: In our view, the bridge is that his critique of Marshall in particular (rather than of marginalism in general) reflects his continuous preoccupation with the analytical and practical consequences of the 'formal symmetry' of production and consumption, and
} 
with Sraffa's more general misgivings about the reinterpretation of the laws of returns to accommodate the marginalist symmetry assumption. What worries him is the persistent reduction of 'descriptive' (qualitative) to 'functional' (physical) relations or curves through the introduction of the universal behavioural assumption of optimisation (substitution). Seen thus, his complaint that "[t]he fact that the "external economies" peculiar to an industry, which make possible the desired conciliation between scientific abstraction and reality, are themselves a purely hypothetical and unreal construction, is something that is often ignored." $(1925,347)$ amounts to an external critique of marginalism in general: the theory is unrealistic not simply in the sense that it is incomplete, but in the sense that the movements it can accommodate and the categories it can handle are generated by the requirements of the theory itself rather than by limitations of knowledge. Put differently, the boxes that are empty are not scientific abstractions that will, in due time, be filled with concrete contents but they are idealisations and can, therefore, never be filled.

As regards Young's 1928 contribution to the debates, the essential point to keep in mind is the difference between his treatment of increasing returns and 'external economies' and that provided by Marshall, as well as the difference of both their notions from Pigou's 'externalities'. It is clear that Marshall and Young had Adam Smith in mind when defining and specifying the concept of increasing returns, i.e., broadly speaking the idea that an increase in the extent of the market allows for a reorganisation of the productive process (division of labour) that, in turn, results in an increase in labour productivity. It is also clear that Young was, to a considerable extent, inspired by Marshall's broad conceptualisation of the sources of increasing returns. Apart from his crucial insight that the division of labour also acts to expand markets, there are two main differences between Young and Marshall: first, Young explicitly rejects Marshall's view that external economies arise within an industry. In his view, it is crucially important to recognise that such economies operate at an economy-wide level, i.e., that 'industrial operations be viewed as an interrelated whole' (1928, 539). Secondly, while Marshall explicitly excludes 'any economies that may result from substantive new inventions' (Marshall 1920, 460), thereby leaving open the door to a static interpretation of increasing returns (i.e., marginal increasing returns to scale arising from equi-proportional factor

his belief that a theory of prices built on marginalist reasoning is incapable of providing a comprehensive and consistent account of dynamic processes (production and accumulation) or capitalist dynamics for that matter. This, after all, also explains why he focused his attention on Marshall rather than any other marginalist. Finally, Pasinetti's recent account of Sraffa's three' streams of thought' in the period between 1926 and 1960, based on a recent 'archival excursus' also appears to us to support this broad perception of continuity in Sraffa's intellectual preoccupation (Pasinetti 2000b, 141-143). 
changes and fixed input $\operatorname{costs}^{8}$ ), Young makes technological change one of the corner stones of his analysis of dynamic (non-marginal ) increasing returns to scale. Ultimately, Young's version of Sraffa's critique of marginalism is that he emphasises (with Adam Smith) the complementary relation between factors of production and replaces the principle of partial factor variation with that of the cumulative nature of economic progress: not only are increasing returns of a dynamic and inter-sectoral nature (including technological change whether of a piecemeal or a radical kind, variable input costs and non-proportional factor changes), but diminishing returns to capital are unlikely ever to set in because capital investment embodies technical change. Neither Marshall's half-heartedly 'dynamic' version of 'external economies' nor Young's much more radical interpretation of them have much, if anything, in common with Pigou's ingenious, but now totally static, definition of an 'externality' as representing a divergence between private and social costs.

\section{VIII}

Having collectively forgotten about the conceptual problems arising from aggregation (of capital or of individual demand functions), modern neoclassical macroeconomics has rediscovered its interest in dynamic analysis, and in the explanation of technical change and 'economic progress' in particular. The most prominent representative of this new neoclassical foray into dynamic analysis is EGT. EGT represents a renewed attempt to unpack the Solowian 'growth residual' or 'measure of our ignorance' (Abramovitz 1956, 11). It aims to provide an endogenous explanation of technological progress within a (macroeconomic) general equilibrium framework. ${ }^{9}$. A central feature of this approach is its focus on the concept of knowledge, both as a factor of production and as a good. A principal claim to originality is that it can accommodate increasing returns.

Analytically speaking, the main characteristic of EGT is the absence of diminishing returns to capital (Barro and Sala-i-Martin 1995, 39, Romer 1994,13-14, Solow 1994, 49 and 2000, 351). In the Solow-Swan model, diminishing returns to both

\footnotetext{
${ }^{8}$ See also Marshall's definition of increasing returns as a quantitative relation: "Increasing Return is a relation between a quantity of effort and sacrifice on the one hand, and a quantity of product on the other" $(1920,319)$.

${ }^{9}$ Our focus here is on the basic analytical structure of the best-known EGT models. While we are well aware of Fine's 'paradox' (Fine 2000: 250) - the discrepancy between very simple basic assumptions, on the one hand, and the sophistication of techniques and axiomatic modelling giving rise to complex outcomes of simple extensions of the basic models, on the other. (see also Pasinetti 2000a, 416) - our purpose in discussing EGT is a limited, illustrative best served by focusing on essentials. Useful surveys are in Revue Economique 1993 (44), Economic Journal 1992 (102), Scandinavian Journal 1992 (95). and the Journal of Economic Perspectives 1994 (8). Recent critical reviews are Cesaratto (1999), Fine (2000) and Banca Nazionale del Lavoro Quarterly Review 2000 (LIII).
} 
factors of production, (physical) capital and labour, together with constant returns to scale are instrumental for the outcome of zero growth per capita in the long period. By contrast, in the story told by EGT, the rate of profits no longer exhibits a tendency to fall and, consequently, the major conclusion of the Solow-Swan model is reversed: An increase in the saving rate now can raise the growth rate of the economy permanently. ${ }^{10}$

Standard EGT identifies two main sources of endogenous growth: reproducible inputs (AK models), and market imperfections in the form of knowledge externalities arising from entrepreneurial efforts and technical change (R\&D models). The first category of models was pioneered by Frankel (1962, see also Cannon 2000); a recent example is Romer (1986). Often supposed to encapsulate the basic message of EGT, these models are built on the assumption of linearity in the differential equation for the production of the factor capital (that stands for all accumulable factors of production) derived from the standard Solow-Swan production function and the equation for capital accumulation. There are two ways of interpreting these models: First, the absence of diminishing returns to capital can be attributed to the elimination of all non-accumulable factors of production from the production function. If, in the Solow-Swan model, diminishing returns to capital are the consequence of taking all other determinants of aggregate output as given implying that labour is non-accumulable in the sense that an increase in output will require a more intensive use of physical capital, the AK models redefine labour as human capital, merging it with physical capital into a single factor. In effect, this assumes an unlimited supply of high quality labour, and hence an exogenously given constant real wage and constant rate of profits independent of the amount of capital employed. Income distribution is thus technologically determined, and if the technology employed uses only self-reproducing inputs (i.e., the rate of capital depreciation is zero), perpetual motion is generated with its rate depending solely on the determinants of saving behaviour and the investment-saving mechanism. This interpretation has been suggested by Kurz and Salvadori (1998, see also Rebelo 1991, Cesaratto 1999 and Solow 2000 for similar interpretations). Secondly, AK

\footnotetext{
${ }^{10}$ Apart from its recognition of the importance to provide an endogenous explanation of technological change, this signals another important motivation of EGT: by reviving the idea that the rate of growth is dependent on saving decisions, it (re)opens the way for orthodox policies aimed at raising the saving rate. EGT is 'pre-Solow-Swan' in that it represents "a return to generalized Domar, but with sophisticated bells and whistles" (Solow 1994:49, similarly Pasinetti 2000a, 416, Cesaratto 1999, 783-785, Fine 2000, 251). However, the bells and whistles are important in one respect: EGT attempts to endogenise technological change by providing a microeconomic explanation based on "the optimising savings behaviour of representative individuals rather than upon a systematic savings rate taken as a parameter for the economy" (Fine 2000, 248). Finally, another important role played by the focus on individual saving behaviour is that it allows us to focus "attention on the steady-state growth rate rather than on transitions between them" since "it can be shown that lengthy transitions from one steady-state path to another occur only if very low intertemporal substitution in consumption is assumed[...]." (Kurz 1998, 48).
} 
models are a special case of Arrow's 'learning-by doing' model (Arrow 1962) with a unity elasticity of learning, the difference being that the source of increasing returns at the aggregate level is specified by linking it to learning processes rather than simply attributing it to capital accumulation per se. In either case, the essential assumption that some externality from capital accumulation ensures constant marginal returns to the accumulable factor along the secular growth path by allowing proportional growth of all factors in efficiency units, has a definite drawback from the point of view of neoclassical distribution theory: In doing away with the assumption of scarcity (decreasing demand curves for capital and labour and partial factor variation), the long-term growth rate no longer equals the rate of growth of the labour supply and factors need no longer be rewarded at their marginal productivity. This also means that the compatibility of the long-term growth path with full capacity utilisation ensured by market forces is no longer guaranteed.

R\&D models can be traced back to Uzawa (1965); important recent examples are Lucas (1988), Romer (1990), Aghion and Howitt (1992 and 1998), Grossman and Helpman (1991a and 1991b). Basically, the scarcity assumption is reintroduced by distinguishing between accumulable and non-accumulable factors of production. The latter are standard physical capital and labour, while there are a number of interpretations of the former (human capital, education, ideas and design, etc.). For simplicity, we call this factor 'knowledge'. Significantly, this additional accumulable factor of production is not scarce in the sense that it is conceptualised as being independent of the supply of labour. Knowledge is assumed to be a self-generating technology and enters the aggregate production function as a constant of some form (i.e., in terms of a constant share of labour time dedicated to knowledge generation, a constant amount of some form of knowledge or a constant increase in labour-augmenting technology generated by innovations). This essential assumption is combined with market imperfection models of technical change in which the consumption choices of a representative agent engaged in (infinite or overlapping-generation horizon) intertemporal utility-maximisation affect the rate of change of productivity and growth. Hence, the main difference between these models and the more abstract AK models is that technical progress is now endogenised in the sense that it is "a special resource-using, profit-seeking activity with its own technology" (Solow 1997,17). Consequently, the theoretical possibilities for generating productivity increases is almost without limit. Important models include variations on horizontal innovation (Romer, Grossman and Helpman) and vertical (or so-called Schumpeterian) innovation (Aghion and Howitt), but once individual (representative) choices affect the future productivity of resources there is, in principle, no limit to the factors that may be taken into account as affecting these choices. 
For our purpose, what is important is not, however, the detail of the specific outcomes of these models, but the basic analytical treatment of knowledge in standard EGT models. Knowledge as a factor of production is self-generating, i.e., not scarce in these models. As with the AK models, the purely analytical assumption of constant returns to the accumulable factor is what ensures that, in the long term, there is a balanced growth path. In terms of the economic explanation of balanced growth dynamics, R\&D models are, however, solely concerned with increasing returns to scale rather than with the absence of diminishing returns to knowledge. Significantly, this shift in emphasis from the 'theory of rent' to the 'theory of economic progress' involves a re-interpretation of knowledge as a (semi-) private good. $\mathrm{R} \& \mathrm{D}$ models of endogenous growth explain increasing returns to scale as arising from externalities, now caused by market imperfections inherent in the process of innovation. What this means, differently from the AK models (where the nature of the externality is not specified), is that the externality is now identical, in nature, with the accumulable factor of production. Knowledge does not just generate externalities, it is an externality. The notion of externalities (to be differentiated from the broader notion of external economies, i.e., dynamic (non-marginal) increasing returns to scale) has meaning only within the static neoclassical benchmark notion of efficient market allocation. Something is an externality because it is external to the market, that is, it cannot be transacted through the market and will therefore not be 'properly' compensated. An externality is the utility of a variable in the production function that is not 'under control' in the sense that it is not reflected in market prices. The efficiency of market allocation is, in turn, a function of two factors: that goods be private goods (i.e., their use is non-rivalrous) and that goods and factors be scarce. The analytical interpretation by EGT of knowledge as a factor of production would suggest that knowledge could also be seen as some form of pre-existing 'public fund' or 'free good' (for each period of production) on which standard factors of production can draw. However, what is emphasised in the context of the microeconomic conceptualisation of innovation processes is the fact that knowledge is not only non-rivalrous, but also partially excludable. This implies that market allocation is at least possible, if not efficient: "The feature that makes a good collective rather than private [...] is the possibility of simultaneous enjoyment of the good, not the possibility of preventing others' enjoyment. The first issue deals with the efficiency of market allocation, the second with its feasibility. Market allocation of public goods may indeed be feasible, but that does not make it efficient." (Marglin 1984, 467/8).

This emphasis on the possibility of 'privatising' knowledge is, however, difficult to reconcile with its presumed ability to generate constant returns to the accumulable factor 
(at the most abstract level, to itself). One of the consequences of introducing private property rights to allow for the private appropriation of returns from knowledge is that this will generate artificial scarcity, certainly with regard to the use (and possible reproduction) of knowledge, and most likely also with respect to its accessibility. This 'paradox' of the R\&D models is easily overlooked in the fog created by the concept of an 'externality'. This concept functions as a 'bridge' between the analytical dynamics of endogenous growth (knowledge as a factor of production) and the static analysis of allocative mechanisms (knowledge as a good).

Hence, neither the AK models nor the R\&D models of endogenous growth provide a substantial explanation of dynamic increasing returns to scale. In the first case, no attempt is made and the validity of neoclassical value (and distribution) theory is simply assumed. ${ }^{11}$ In the second case, the notion of externalities allows EGT to ignore the implications arising from its mathematical formulation of balanced growth dynamics in favour of an economic interpretation that opens the way to safeguard, if not competitive value theory, at least the institutional framework of a private market economy.

What this discussion highlights is that Sraffa's as well as Young's (and Schumpeter's) early misgivings about the ability of neoclassical value theory to account in a non-restrictive manner for processes of accumulation, first raised in the 1920s debates, has not been disproven by recent developments in neoclassical growth theory.

\section{IX}

As pointed out, there are more damning criticism of EGT (regarding its use of aggregate capital) and of the new classical macroeconomics in general (concerning its disregard of the Sonnenschein-Mantel-Debreu results) that have arisen from later theoretical developments. The reason the 1920s debates remain (at least in part) modern in spirit is that they deal, in a few clear-sighted contributions, with one of the root causes of the present unsatisfactory state of affairs. The point is that even if, for the sake of the argument, we were prepared to ignore the regressive turn taken by the "new classical macroeconomics', of which EGT is one important instance, - that is, even if we were prepared to overlook the fact that a microeconomic theory of general equilibrium is simply being interpreted as a macroeconomic theory - neoclassical theory is still unable to provide a substantial and consistent (non-ad hoc) explanation of growth dynamics.

\footnotetext{
${ }^{11}$ Significantly, where attempts at an economic explanation are made, this involves Marshallian
} 
This root cause is that the logic of marginalism imposes a symmetry requirement for the analysis of the separate spheres of consumption and production that proves inadequate for understanding and conceptualising the fundamentally dynamic processes driving economic organisation and progress. Attempts to maintain this symmetry create more empty boxes that cannot be filled. Thus, what matters from today's point of view is Sraffa's external criticism of the symmetry assumption that applies equally to partial and general equilibrium analysis: The 'knowledge factor' of EGT is just as empty a box as the 'representative firm' - and for that matter the 'representative agent or individual' - not because our scientific tools are insufficient to deal with real complexities, but because these theoretical constructions are idealisations generated by the requirements of the theory in the first place.

The restrictive nature of these concepts lies in the fact that they assume what should be explained. Since the concept of the 'representative firm' was so essential to Marshall's attempt to safeguard marginalist analysis in the sphere of production as well as to the 1920 s debates that tried to come to grips with this attempt, it is worthwhile to briefly draw out the parallels between this concept and the role played by the 'knowledge factor', and 'knowledge externalities' in particular, in EGT. The debate about what exactly the representative firm stands for - that is, whether it is, in a metaphorical sense a biological or a mechanical concept - has recently flared up again (e.g. Hart 1996, Marchionatti 2000, Raffaelli 2000). For our purpose, there is no need to decide whether the 'representative firm' was meant to encapsulate the growth path of a firm or average (normal) industry expenses for a given aggregate volume of production in competitive conditions (especially given that Marshall himself maintained his usual ambiguity on this question). What is important is that Marshall considered this concept particularly relevant for an explanation of industries operating with increasing returns (Principles 1920: 376). It allows Marshall to ignore the impact of radical innovations at the aggregate (industry) level, and thus to reconcile firm disequilibrium with aggregate (industry) equilibrium by assuming that technical change will be of a such a gradual and piecemeal nature at aggregate level that competitive equilibrium prevails. The device of blurring the difference between knowledge as a factor of production and as a good employed by EGT achieves exactly the same: it allows EGT to ignore the cumulative nature of embodied technical progress. In this case, the analytical 'bridge' between static and dynamic analysis is provided by the concept of 'knowledge externalities'. The difference from Marshall is that increasing

internal-external economies (e.g. Romer 1986). 
returns are not now the result of a proportional increase of all factors in a single industry, but of an economy-wide scale effect arising from the greater efficiency of given amounts of non-accumulable factors of production due to the larger use of a self-generating (accumulable) factor of production called knowledge. In neither case are Youngian dynamic increasing returns or, more precisely, the processes underlying accumulation, explained. As both Sraffa and Young pointed out, "[w]ith the extension of the division of labour, the representative firm, like the industry of which it is a part, loses its identity." (Young 1928, 538, see also Sraffa 1930, 91-92). Similarly, EGT never actually explains the processes and mechanism that underlie the self-generating nature of knowledge as a factor of production. Rather, the analytical purpose of both the 'representative firm' and of 'knowledge externalities' is that they admit precisely those changes and movements that are a priori compatible with the theory. The cumulative nature of embodied technical progress is not among these. ${ }^{12} 13$

The contributions to the 1920s debate by Sraffa, Young and Schumpeter can thus be seen to provide a common basis from which to re-appreciate the "the real source of the trouble, [i.e.,] the confusion between comparisons of equilibrium points and the history of a process of accumulation" (Joan Robinson 1975, 34). It is also well known that they differed in one respect: both Young and Schumpeter took the view that static analysis was simply different from dynamic analysis - a separate world, so to speak - and chose to concentrate on the latter. Sraffa refused to leave the terrain of the theory of value and prices to the neoclassicals. The result has been the emergence of two different research agendas: Sraffa went on to provide us with a consistent, general and asymmetric theory of prices, distribution and reproduction that allows for an encompassing analysis of dynamics. Kaldor took up and developed Young's suggestions for a theory of embodied technical progress and capitalist accumulation. Not altogether surprisingly, it was Schumpeter who has been 'revived' by EGT since, of the three authors mentioned here, he remained the

\footnotetext{
${ }^{12}$ Aghion and Howitt say as much in a footnote on their treatment of (physical) capital accumulation: "There are many reasons for thinking that policies that favor capital accumulation will generally also stimulate innovation and raise the long-run growth rate", adding in a footnote that "[a]nother reason, which does not however fit easily into the present framework, is that capital goods embody technologies." (Aghion and Howitt 1998, 102). When EGT models have begun to tackle dynamic analysis more profoundly, "all [these] contributions [...] have been introduced from outside neoclassical theory, even when - as has happened for those contributions that, by being published in the major (mainstream) journals have attracted most attention - they have been inserted into neoclassical theory." (Pasinetti 2000a, 419)

${ }^{13}$ A similar methodological argument applies to the use made of the concept of the 'individual agent' not just by EGT but the 'new classical' macroeconomics in general. This, though, does not relate to the analysis of the role played by technical progress in capital accumulation. Rather, as Pasinetti has pointed out, '[i]t becomes pure nonsense to speak of income distribution." (Pasinetti 2000a, 418). For an excellent critique of the representative individual from the point of view of general equilibrium theory see Kirman (1992).
} 
most ambivalent with regard to the compatibility of his theory of development with marginalist analysis, an impression often - wrongly or rightly - reinforced by his almost unbounded admiration for Walras. ${ }^{14}$

On the basis of our discussion above, the most promising, and also the most challenging, task for the future is to reunite these two traditions of research. As Pasinetti has pointed out recently (2000a, 422), this would imply much more than a mere 'tying together' of existing insights. Even if we consider the recent developments of 'new classical' macrotheory to unsatisfactory, it does not follow that the issues addressed are secondary: The social fabric of modern capitalism changed considerably since the heyday of Sraffa and Kaldor. Whether or not the material basis of technical progress in capitalism has changed - whether or not, therefore, we are moving towards a knowledge-driven economy - and what exactly this entails are questions that deserve answers.

\section{References}

Abramovitz, M. (1956), "Resource and output trends in the United States since 1870", American Economic Review, 46, 5-23.

Aghion, P. and P. Howitt (1992), "A model of growth through creative destruction", Econometrica, 60 (2), 323-351.

Aghion, P. and P. Howitt (1998), Endogenous Growth Theory, Cambridge, Mass.: MIT Press.

Arena, R. and A. Raybaut (2001), "Neo-Schumpeterian versus Neo-Kaldorian Approaches: Two different views on learning, knowledge and cyclical growth" in H. Hagemann and S. Seiter (eds), Growth Theory and Growth Policy, London: Routledge.

Arena, R. (1990), "Introduction" in R. Arena and J.-L. Ravix (eds) (1990), Sraffa. Trente ans après, Paris: Presses Universitaires de France.

Arrow, K. J. (1962), "The economic implications of learning by doing", Review of Economic Studies, 29 (3), 155-173.

Barro, R. and X. Sala-i-Martin (1995), Economic Growth. New York: Mc Graw-Hill.

Cannon, E.S. (2000), "Economies of scale and constant returns to capital: a neglected early contribution to the theory of economic growth", American Economic Review, 90 (1), 292-295.

Cavalieri, D. (2000), "On some controversial aspects of Sraffa's theoretical system in the second half of the 1920s", in: T. Cozzi and R. Marchionatti (eds) (2000), Piero

\footnotetext{
${ }^{14}$ But see Arena and Raybaut (2001) for an assessment of the conceptual difference between Schumpeter and 'Schumpeterian' EGT.
} 
Sraffa's Political Economy. A centenary estimate. London and New York: Routledge, 100-120.

Cesaratto, S. (1999), "Savings and economic growth in neoclassical theory", Cambridge Journal of Economics, 23, 771-793.

Clapham, J. H. (1922), “On empty boxes”, Economic Journal, 32, 305-314.

Dardi, M. (2000), "Why did Sraffa lose interest in imperfect competition? A comment on Marcuzzo" in: T. Cozzi and R. Marchionatti (eds) (2000), Piero Sraffa's Political Economy. A centenary estimate. London and New York: Routledge,128-135.

Fine, B. (2000), "Endogenous growth theory: a critical assessment", Cambridge Journal of Economics, 24, 245-265.

Frankel, M. (1962), “The production function in allocation and growth: A synthesis", American Economic Review, 52, 995-1002.

Grossman, G. and E. Helpman (1991a), Innovation and Growth in the Global Economy, Cambridge, Massachussetts, MIT Press.

Grossman, G. and E. Helpman (1991b), "Quality Ladders in the Theory of Growth", Review of Economic Studies, 106 (2), 43-61.

Hart, N. (1996), "Marshall's theory of value: the role of external economies", Cambridge Journal of Economics 20, 353-369.

Keynes, J.M. (1930) (ed.), "Increasing returns and the representative firm. A symposium. (with contributions by D.H. Robertson, P. Sraffa and G.F. Shove)", Economic Journal, 40, 79-116.

Kirman, A. (1992), “Whom or what does the representative individual represent?", Journal of Economic Perspectives, 6 (2), 117-136.

Kurz, H. (1998), "The path of economic growth theory: some recent developments" in: H. Hagemann and H. Kurz (eds) (1998), Political Economics in Retrospect. Essays in Memory of Adoph Lowe, Cheltenham: Edward Elgar, 43-75.

Kurz, H.D. (2000), Critical Essays on Piero Sraffa's Legacy in Economics, Cambridge: Cambridge University Press.

Kurz, H. and N.Salvadori (1998), "What is new in the "New Growth Theory? Or: Old Wine in New Goatskins" in Coricelli, F et al (eds) (1998), Growth and Development: Theories, Empirical Evidence and Policy Issues, London: Macmillan.

Lucas, R. (1988), "On the mechanics of economic development", Journal of Monetary Economics, 22 (1), 3-42.

Marchionatti, R. (1999), "On the methodological foundation of modern microeconomics. Frank Knight and the 'cost controversy' in the 1920s", mimeo, Department of Economics, University of Turin/University of Cambridge.

Marchionatti, R. (2000), "Sraffa and the criticism of Marshall in the 1920s" in: T. Cozzi and R. Marchionatti (eds) (2000), Piero Sraffa's Political Economy. A centenary estimate. London and New York: Routledge, 43-81. 
Marcuzzo, M.C. (2000), "Sraffa and Cambridge economics, 1928-1931" in: T. Cozzi and R. Marchionatti (eds) (2000) Piero Sraffa's Political Economy. A centenary estimate. London and New York: Routledge, 81-100.

Marglin, S. (1984), Growth, Distribution and Prices, Cambridge, Mass: Harvard University Press.

Mongiovi, G. (1996), "Sraffa's critique of Marshall: a reassessment", Cambridge Journal of Economics, 20, 207-224.

Pasinetti, L. L. (2000a), "Critique of the neoclassical theory of growth and distribution", Banca Nazionale del Lavoro Quarterly Review, LIII (215), 383-433.

Pasinetti, L.L. (2000b), "Continuity and change in Sraffa's thought: an archival excursus" in: T. Cozzi and R. Marchionatti (eds) (2000), Piero Sraffa's Political Economy. A centenary estimate. London and New York: Routledge, 139-156.

Pasinetti, L.L. and R. M. Solow (eds) (1994), Economic Growth and the Structure of Long-Term Development. Proceedings of the IEA Conference held in Varenna, Italy, Basingstoke: Macmillan.

Pigou, A.C. (1922), "Empty boxes: a reply”, Economic Journal, 32, 458-465.

Pigou, A.C. (1927), "The laws of diminishing and increasing costs", Economic Journal, 37, 188-197.

Pigou, A.C. (1928), “An analysis of supply”, Economic Journal, 38, 238-257.

Raffaelli, T. (2000), “On Marshall's representative firm: a comment on Marchionatti.”, in: T. Cozzi and R. Marchionatti (eds) (2000), Piero Sraffa's Political Economy. A centenary estimate. London and New York: Routledge, 123-127.

Rebelo, S. (1991), "Long run policy analysis and long run growth", Journal of Political Economy, 99 (3), 500-521.

Rizvi, S. A.T. (1994a), "The microfoundations project in general equilibrium theory", Cambridge Journal of Economics, 18, 357-377.

Rizvi, S.A.T. (1994b), "Game theory to the rescue?", Contributions to Political Economy, 13, $1-28$.

Robbins, L. (1928), “The representative firm”, Economic Journal, 38, 387-404.

Robinson, J. (1975), “The unimportance of reswitching”, Quarterly Journal of Economics, 89, 32-9.

Robertson, D.H. (1924), "Those Empty Boxes (with a comment by A.C. Pigou and rejoinder by D.H. Robertson), Economic Journal, 34, 16-31.

Romer, P. (1986), “Increasing returns and long-run growth”, Journal of Political Economy 94 (5), 1002-1037.

Romer, P. (1990), "Endogenous technological change, Journal of Political Economy 98 (5), 71-102. 
Romer, P. (1994), "The Origins of Endogenous Growth", Journal of Economic Perspectives 8 (1), 3-22.

Salter, W. E.G. (1960), Productivity and Technical Change, Cambridge: Cambridge University Press, $2^{\text {nd }}$ edition 1966.

Schumpeter, J.A. (1928), “The Instability of Capitalism”, Economic Journal, 38, 361-386.

Schumpeter, J.A. (1994 [1954]), A History of Economic Analysis.London: Routledge.

Shove, G.F. (1928), "Varying costs and marginal net products", Economic Journal, 38, 258-266.

Solow, R.M. (1994), "Perspectives on growth theory", Journal of Economic Perspectives 8 (1), 45-54.

Solow, R.M. (1997), Learning from Learning by Doing. Lessons for Economic Growth, Stanford, California: Stanford University Press.

Solow, R.M. (2000), "The neoclassical theory of growth and distribution", Banca Nazionale del Lavoro Quarterly Review, LIII (215), 277-328.

Sraffa, P. (1925), "Sulle relazioni fra costo e quantità prodotta", Annali di Economia, 2, 277-328. English translation by John Eatwell and Alessandro Roncaglia in L.L. Pasinetti (ed.), Italian Economic Papers, vol. 3, Bologna: Il Mulino 1998 and Oxford: Oxford University Press 1998: pp. 323-363.

Sraffa, P. (1926), "The laws of returns under competitive conditions", Economic Journal, 36, 535-550.

Sraffa, P. (1960), Production of Commodities by Means of Commodities. Prelude to a Critique of Economic Theory, Cambridge: Cambridge University Press.

Sraffa, P. (1961), "Comment" in: F.A. Lutz and D.C. Hague (eds) (1961), The Theory of Capital, London: Macmillan, pp. 305-306.

Whitaker, J.K. (1982), "Increasing Returns and External Economies: Some Early Developments", paper presented to the Annual Meetings of the History of Economics Society, Duke University.

Whitaker, J. K (1989), “The Cambridge background to imperfect competition”, in: Feiwel, G.R. (ed.) (1989), The Economics of Imperfect Competition and Employment: Joan Robinson and Beyond, London: Macmillan.

Uzawa, H. (1965), "Optimum technical change in an aggregate model of economic growth", International Economic Review, 6, 18-31.

Young, A. (1928), "Increasing returns and economic progress", Economic Journal, 38, 527-542. 